\title{
PROGRAM PENGEMBANGAN KEWIRAUSAHAAN (PPK) USAHA TANAMAN HERBAL MAHASISWA FAKULTAS PERTANIAN UNIVERSITAS JAMBI
}

\author{
Rainiyati $^{1}$, Ahmad Riduan ${ }^{1}$, Sarah Fiebrina Heraningsih ${ }^{2}$ \\ ${ }^{1}$ Fakultas Pertanian, Universitas Jambi \\ ${ }^{2}$ Fakultas Teknik, Universitas Jambi \\ Email : rainiyati@unja.ac.id
}

\begin{abstract}
ABSTRAK
Program Pengembangan Kewirausahaan (PPK) Produk Unggulan Pertanian Demi Terciptanya Agropreneur Muda berfokus pada usaha-usaha bidang pertanian. Fokus usaha yang dijalankan yaitu tanaman herbal. Adanya unit usaha ini diharapkan menjadi wadah kreatifitas dan memancing inovasi dari mahasiswa disamping itu akan menghasilkan income untuk kemandirian mahasiswa.
\end{abstract}

\section{Kata Kunci : tanaman herbal, kewirausahaan, magang}

\section{PENDAHULUAN}

Fakultas Pertanian Universitas Jambi memliki 2 program studi S1 yaitu Agroekoteknologi dan Agribisnis serta D3 Agrobisnis. Mahasiswa Fakultas Pertanian memiliki minat yang cukup besar untuk melakukan wirausaha yang dilihat pada tahun 2016, terdapat 10 proposal PKM-K yang di adakan oleh kemahasiswaan Fakultas Pertanian untuk di danai. Tahun 2017, jumlah proposal yang masuk untuk didanai adalah 28 proposal yang sangat meningkat dari tahun 2016. Banyak dari proposal yang didanai begerak di budidaya ataupun pengelolaan produk pertanian.

Ide usaha yang dihasilkan sangat menarik untuk di kembangkan, adapun bidang usaha yang menarik untuk di kembangkan adalah pengembangan produk pertanian tanaman herbal. Kegiatan produk pertanian ini sangat memungkinkan mendapat peluang pasar yang besar di Provinsi Jambi, karena minimnya wirausaha di bidang pertanian yang serupa, selain itu usaha yang akan/sedang dilaksanakan memiliki keunggulan dalam memanfaatkan tanaman pertanian yang berbasis tanaman herbal yang akan didukung oleh dosen-dosen yang mempuni di bidangnya.

Usaha tanaman herbal merupakan sebuah usaha dibidang pertanian dengan sistem melakukan perbanyakan. Di Provinsi Jambi, sulit didapatkan bibit tanaman herbal yang berkualitas terlebih bibit stevia dan mint. Sehingga prospek pengembangan usaha ini sangat menjanjikan. Kesiapan pengelola Fakultas Pertanian Universitas Jambi saat ini telah baik, hal ini ditandai dengan keberlangsungan kegiatan kewirausahaan di Fakultas Pertanian yang dilaksanakan berjalan dengan baik dan menunjukkan kurva pertumbuhan setiap tahunnya, dan juga didorong oleh dukungan pihak dekanat yang mendukung kegiatan kewirausahaan di Fakultas Pertanian Universitas Jambi, dimana dekan langsung memegang peran dan bertanggung jawab dalam kegiatan ini. Sarana yang disediakan fakultas juga cukup mendukung dalam kegiatan kewirausahaan. Sehingga dapat membantu mahasiswa khususnya dalam pengembangan kewirausahaannya dibidang pertanian.

\section{METODE KEGIATAN}

Kegiatan Program Pengembangan Kewirausahaan (PPK) dirancang untuk membekali mahasiswa Fakultas Pertanian untuk berwirausaha. Salah satu unit usaha yang dikembangkan ialah usaha tanaman herbal. Pada Kegiatan PPK ini diawali dengan kegiatan seleksi mahasiswa hingga dipilih 5 orang tenant yang diberi pembekalan mengenai wirausaha tanaman herbal. Setelah terpilih kelima orang tenant diberi pembekalan untuk magang setelah itu dipihlah tempat magang yang sesuai dengan bidang tanaman herbal. Kegiatan magang ini bertujuan agar mahasiswa dapat terjun langsung ke lokasi usaha sehingga mahasiswa memiliki pengalaman yang sesuai dengan bidang usaha. Lokasi yang dipilih untuk magang ialah Kampoeng Djamoe Organik Martha Tilaar yang berada di Cikarang-Bekasi. Lokasi tersebut dipilih karena Kampoeng Djamoe Organik Martha Tilaar telah memiliki banyak produk terkait dengan 
tanaman herbal serta tujuan dari berdirinya perusahaan tersebut sangat bagus, yaitu pengelolaan lingkungan yang berasaskan pemanfaatan dan pelestarian yang secara seimbang sehingga dapat memberikan manfaat bagi masyarakat secara umum.

\section{Metode Pelaksanaan}

Kegiatan magang dilaksanakan menggunakan metode Observasi dan metode partisipasi aktif. Metode observasi adalah pengamatan secara langsung yang dibimbing oleh pembimbing lapangan atau karyawan di perusahaan. Metode partisipasi aktif ialah mengikuti setiap kegiatan di Kampoeng Djamoe Organik Martha Tilaar.

\section{Metode Pengumpulan Data}

Pengumpulan data bersumber dari Tanya jawab secara langsung atau wawancara dengan Pembimbing lapangan dan pemilik perusahaan yang bertujuan untuk mendapatkan data yang diperlukan dalam kegiatan magang ini. Selain itu juga diperoleh dari sumber tertulis mengenai cara pemasaran ke perusahaan yang akan ditujukan.

\section{HASIL DAN PEMBAHASAN}

Kegiatan magang Tanaman Herbal ditempatkan di Kampoeng Djamoe Organik Martha Tilaar, Cikarang, Bekasi, Jawa Barat. Kegiatan dilaksanakan pada tanggal 20 Juli 2018 sampai dengan 20 Agustus 2018. Selama kegiatan magang berlangsung, Tenant PPK ditempatkan di Wilayah usaha Kampoeng Djamoe Organik Martha Tilaar yaitu di Cikarang- Bekasi. Tenant mendapatkan berbagai informasi selama kegiatan berlangsung. Diantaranya informasi mengenai sejarah perusahaan tersebut hingga cara memasarkan produk tanaman herbal tersebut dan tenant juga diajarkan cara membudidayakan tanaman herbal yang baik dan benar serta mendapatkan nilai jual yang tinggi.

\section{Profil Perusahaan Kampoeng Djamoe Organik Martha Tilaar (KaDO)}

KaDO merupakan lahan hijau dengan konsep taman organik yang terletak di kawasan kota Cikarang dengan areal seluas 10 ha yang cukup strategis dan mudah dijangkau. Pada awalnya berupa kebun yang menyediakan koleksi tanaman obat, kemudian $\mathrm{KaDO}$ mulai difungsikan sebagai pusat pendidikan lingkungan karena memiliki berbagai koleksi tanaman obat asli Indonesia (ada sekitar 600 spesies tanaman) yang dibudidayakan secara organik selaras dengan alam. Di area pasca panen juga terjadi proses penanganan bahan baku tanaman hasil panel hingga menghasilkan bahan yang berkualitas dan berstandar. Cikarang, 29 Januari 2011 - PT. Martina Berto Tbk. - Martha Tilaar Group menaruh perhatian yang mendalam terhadap pelestarian lingkungan. Dengan moto Local Wisdom Go Global, PT. Martina Berto Tbk. bervisi menjadi perusahaan kosmetika dan spa (beauty \& spa) terkemuka di dunia yang bernuansa ketenanturan dan alami melalui pemanfaatan teknologi modern dan menempatkan penelitian dan pengembangan sebagai sarana peningkatan nilai tambah bagi konsumen dan pemangku kepentingan lainnya. (Anonim_b, 2018)

Salah satu wujud nyata dari kepedulian ini terwujud dalam pendirian Kampoeng Djamoe Organik (KaDO) di kawasan kota Cikarang. Pendirian lahan hijau seluas 10 ha ini pun sejalan dengan salah satu dari 4 pilar Value of Martha Tilaar Group, yaitu Beauty Green. Kehadiran KaDO memiliki tujuan sebagai: Salah satu program pelestarian kekayaan alam Indonesia, khusunya TOKA (Tanaman Obat, Kosmetika dan Aromaterapi). Indonesia memiliki 33 ribu spesies flora yang bisa diteliti untuk kepentingan kecantikan dan kesehatan. KaDO sudah memulai dengan mengkonservasi dan membudidayakan lebih dari 500 jenis TOKA. Cikal bakal akan sebuah pabrik yang hijau dan ramah lingkungan.(Anonim_a, 2014)

\section{Jenis dan Kegiatan Magang}

Sebelum melaksanakan kegiatan magang di Perusahaan Tanaman Herbal Bekasi, Jawa Barat. Tenant diberikan bimbingan dan pembekalan dari karyawan yang bekerja di tanaman herbal KaDO. Pembekalan yang dimaksud ialah untuk mengetahui awal mula terbentuknya tanaman herbal KaDO. Pada hari berikutnya tenant mulai melakukan magang ataupun praktek langsung di lapangan sesuai dengan tujuan dari magang ini. 


\section{Prosedur Magang}

Berdasarkan pada jadwal pelaksanaan kegiatan magang yang telah ditetapkan maka kegiatan magang dimulai dari tanggal 20 Juli 2018 sampai dengan 20 Agustus 2018. Setelah ditentukan jadwal magang, tenant langsung ditempatkan dibagian pembibitan, penanaman, perawatan, pengemasan hingga ke pemasarannya.

\section{Kegiatan Magang di Cikarang Barat (20 Juli 2018-20 Agustus 2018)}

Selama magang di Kampoeng Djamoe Organik Martha Tilaar mempelajari cara budidaya Tanaman Herbal sampai pelabelan. Selain itu Tenant juga mempelajari tentang pengolahan herbal juice, simplisia, dan pembuatan pupuk kompos. Dimulai dari membuat atau praktek langsung hingga pembuatan jamu di Kampoeng Djamoe Organik Martha Tilaar.

Di Kampoeng Djamoe Organik Martha Tilaar tenant diberikan jadwal kegiatan yang harus dikerjakan selama magang, yaitu:

a.)Pengenalan area kado.

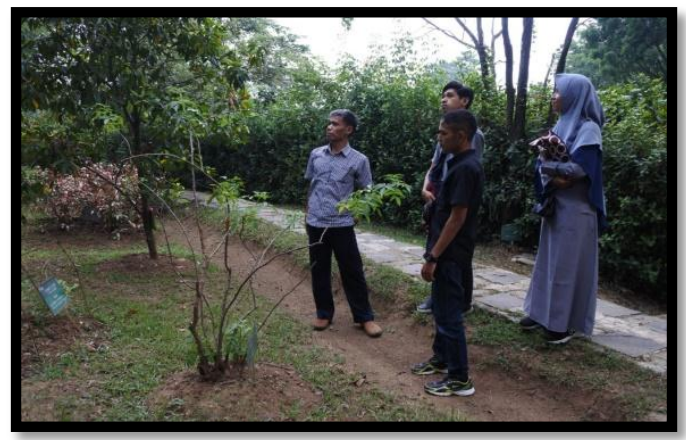

b.)Identifikasi tanaman OKA

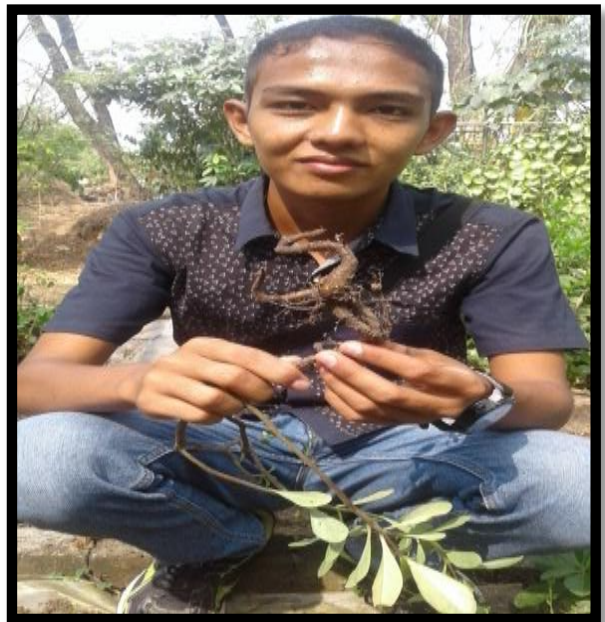

c.)Praktek perbanyakan tanaman

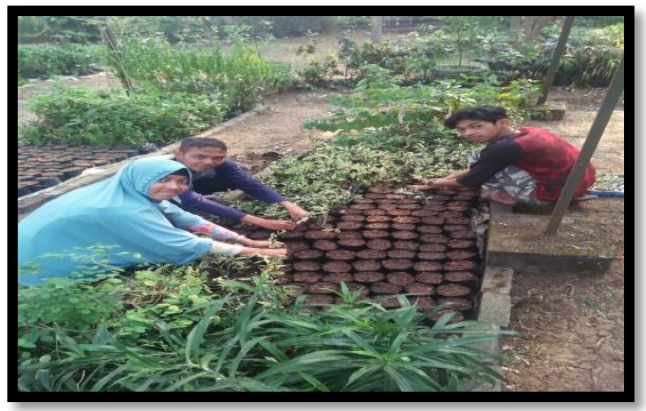

d.)Praktek budidaya tanaman
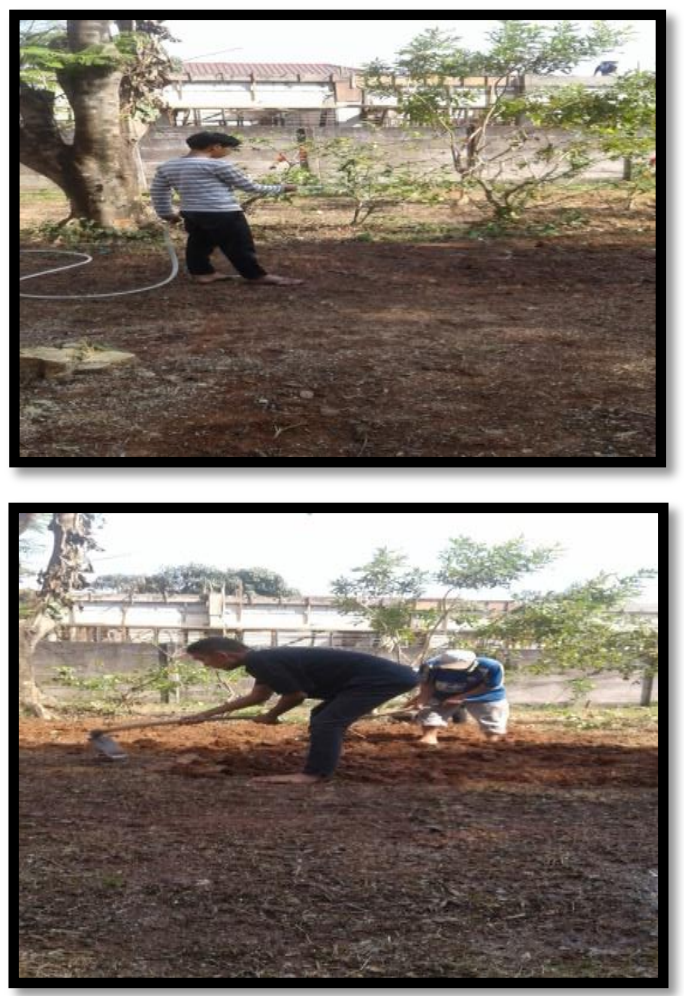

Pengelolahan tanah ke

Pembuatan bedengan dan pembuatan lubang






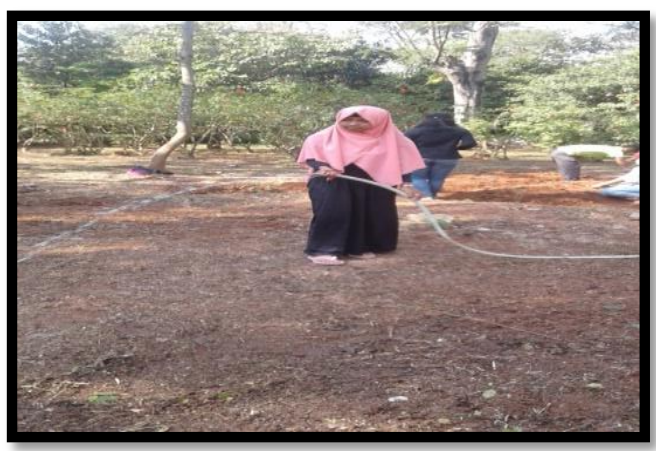

Penanaman Perawatan Tanaman

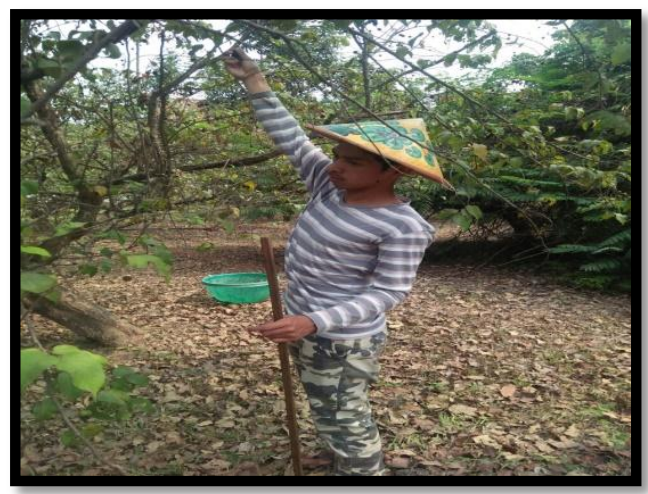

Pemanenan

e.)Praktek pengelolahan kompos

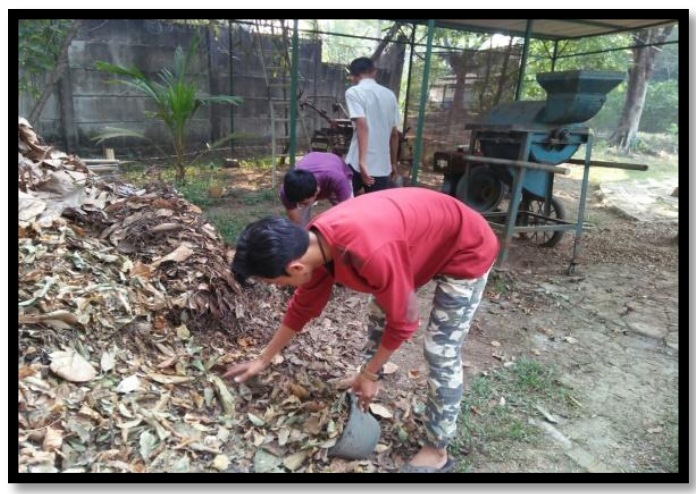

f.)Praktek pengelolaan pasca panen



g.)Praktek pembuatan jamu sederhana
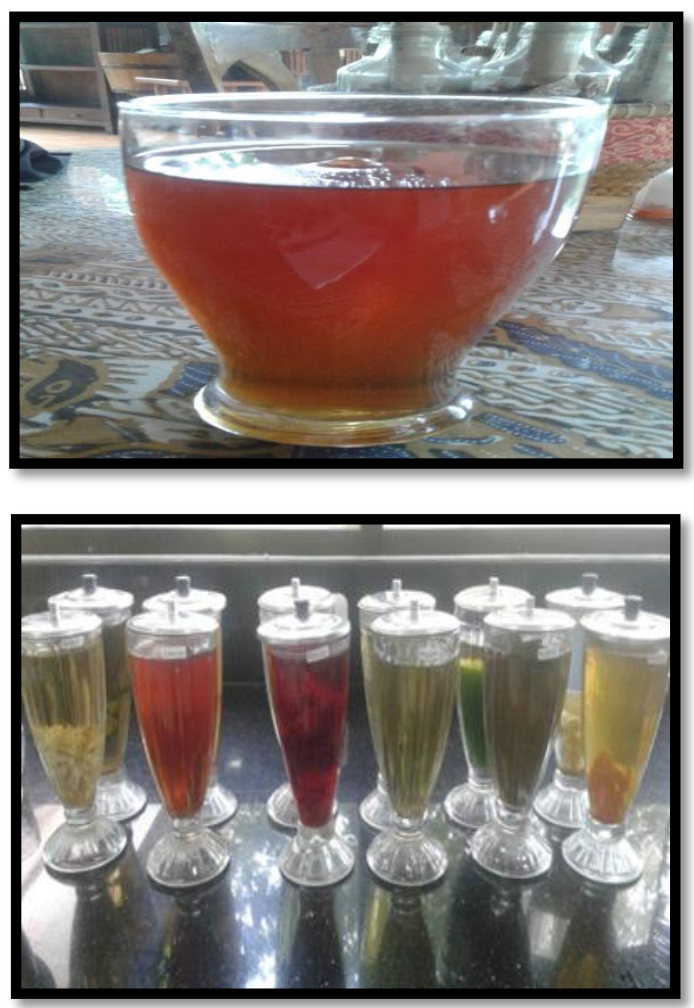

Herbal Juice Beras Kecur/Kunyit asam

\section{KESIMPULAN}

Berdasarkan kegiatan program pengembangan program pengembangan kewirausahaan (ppk) usaha tanaman herbal mahasiswa fakultas pertanian universitas jambi didapatkan kesimpulan sebagai berikut :

1. Kampoeng Djamoe Organik Martha Tilaar sangat bersahabat dan cukup mengayomi bagi setiap peserta magang. Adanya bimbingan dan arahan yang baik dari pementor dalam pelaksanaan kegiatan magang.

2. Tenant lebih dapat memahami interaksi kerja dengan sinergi kerja dan mengenal dunia kerja yang sesungguhnya dalam bidang pertanian khususnya tanaman herbal.

3. Adanya kerjasama yang baik dalam melaksanakan setiap pekerjaan, sikap ingin tahu yangg tinggi dan mau belajar, serta adanya bibingan yang tepat sehingga transformasi ilmu dan arahan pementor dapat dipahami oleh peserta magang dengan baik dan tepat sasaran merupakan faktor khusus yang membantu kegiatan peserta magang. 


\section{UCAPAN TERIMAKASIH}

Ucapan terimakasih yang sebesar-besarnya kami ucapkan kepada Kementerian Riset, Teknologi dan Pendidikan Tinggi yang telah mendukung dan mendanai Program Pengembangan Kewirausahaan (PPK) Produk Unggulan Pertanian Demi Terciptanya Agropreneur Muda hingga bisa berjalan dengan baik.

\section{REFERENSI}

Anonim_a. 2014. Profil Kado. Diakses tanggal 15 Agustus 208 pukul 12.25 WIB dari http://www.kampoengdjamoemarthatilaar.com/

Anonim_b. 2015. Produk Herbal Kado. Diakses tanggal 15 Agustus 208 pukul 12.30 WIB dari http://www.kampoengdjamoemarthatilaar.com/ 